\title{
An Analysis of University Students' Perspective on Online Learning in the Midst of Covid-19 Pandemic
}

\author{
Sujarwo $^{1, *}$, Sukmawati $^{2}$, Akhiruddin $^{3}, \operatorname{Ridwan}^{4}$, Suharti Siradjuddin $^{5}$ \\ ${ }^{1}$ Prodi Pendidikan Bahasa Inggris Fakultas Keguruan dan Ilmu Pendidikan (FKIP) Universitas Megarezky. Jl. Antang Raya \\ No. 43 Makassar, Indonesia. \\ ${ }^{2}$ Prodi Pendidikan Bahasa Inggris Fakultas Keguruan dan Ilmu Pendidikan (FKIP) Universitas Megarezky. Jl. Antang Raya \\ No. 43 Makassar, Indonesia. \\ ${ }^{3}$ Prodi Pendidikan Sosiologi Fakultas Keguruan dan Ilmu Pendidikan (FKIP) Universitas Megarezky. Jl. Antang Raya No. \\ 43 Makassar, Indonesia \\ ${ }^{4}$ Prodi Sastra Indonesia, FIB, Universitas Unkhair, Ternate Indonesia. \\ ${ }^{5}$ Prodi Pendidikan Bahasa Inggris Fakultas Keguruan dan Ilmu Pendidikan (FKIP) Universitas Megarezky. Jl. Antang \\ Raya No. 43 Makassar, Indonesia. \\ *Corresponding Authore-mail: jarwo.ibrahim@gmail.com
}

\begin{abstract}
In this study we address and investigate university students' perspective on utilizing online learning in the midst of COVID19 pandemic. This research used qualitative descriptive method. The subject of this research were the learners of Elementary School Teacher Education, Physical Education, Sociology Education and English Education Department of Universitas Megarezky in 2019/2020 academic year. The number of respondents was 40 respondents. The research instruments were questionnaire that was obtained by google form through analyzing participants' response to know their perspective in using online learning and in-depth interview. The study showed that previously, students did not use online learning before the pandemic because learning was conducted in the classroom. In the midst of covid-19 pandemic, the students are interested in using online learning in which can be accessed flexible, anywhere and everywhere. The best application used by lecturers and students was WhatsApp application. It can be concluded that the students' perspective on online learning had a positive impact in the midst of the covid-19 pandemic.
\end{abstract}

Keywords: Students' perspective; online learning; COVID-19 pandemic; university students

\section{Introduction}

The epidemic of the Coronavirus Novel 2019 (2019-nCoV), which continues to expand, causing the worldwide COVID-19 Pandemic to cause the first global health crisis in the millennium era after the Spanish Flu Pandemic in 1918 (Hasanah et al., 2020). COVID19 Pandemic has a massive impact on global human life. In fact, based on a report made by Suminar (2020) the Covid-19 pandemic could make the global economy shrink to one percent in 2020, and could contract further if the restriction of economic activity was extended without adequate fiscal response. World Health Organization (WHO) has established the phenomenon of the incident as a pandemic (Mahase, 2020). Pandemic occurs when an infectious disease spreads easily from humans to humans in various places throughout the world (Rusdiana et al., 2020). Pandemic of COVID-19 was felt also by the world of education. Rajab (2020) as the director of Ma'had and Islamic Studies Tazkia International Islamic Boarding School, Malang, quoted from detik News, that the effects of the Corona Virus is now also perceived by the education world. This has been recognized by 
the United Nations education, Scientific and Cultural Organization (UNESCO) on Thursday (5/3), that Corona virus outbreak has impacted the education sector. Nearly 300 million students interrupted their school activities around the world and threatened their future education rights. The previous day, 13 countries including China, Italy, and Japan had closed schools around the country in an attempt to stop the spread of the virus. It affects nearly 290 million students as cited in Deli \& Allo, 2020.

The closure of schools and educational facilities is the choice of many countries, both at the primary and university level throughout Indonesia, especially in South Sulawesi (Makassar). This reality caused panic at the National Examination (UN). All levels of educational institutions in Indonesia, especially tertiary institutions feel as one of the institutions affected by the spread of covid-19 adverse effects caused by students are required to learn online from home because of the cessation of direct learning face to face in class to break the chain and exposure to the corona virus.

Furthermore, they are used to design project-based learning activities, when the COVID-19 outbreak compelled all schools to close and students to learn from home, they hardly faced adjustment issue. At worst, however, learning is just not happening for several students. Their lecturers lack resources to interact in online learning and plenty of students do not have access to net affiliation and also the necessary gadgets (Lie, 2020). Online learning represents a serious shift in however individuals learn and successively, even the learners square measure schooled. Then, Allen and Seaman (2013) report looked at online education, including the growing presence of massive open online courses (MOOCs), from the institutional perspective, not from the students as cited in Cole et al. (2014). The use of elearning or online learning become essential for higher education institutions and they are considering and accepting this fact in order to compete with other organizations and for meeting financial stability (Stefanovic et al., 2011). Sanjaya (2020) studied in 21 century reflections of online learning in the emergency period Covid-19, and Yanti, M. T., Kuntarto, E., \& Kurniawan (2020) studied the use of the Ministry of Education and Culture learning portal as an online learning medium in elementary schools. Based on the report, a study of obstacles, solutions and projections of online learning systems for prospective acade mics has never been done as cited in (Jamaluddin et al., 2020). With the event of IT, many pe rsons do innovation of IT which will be accustomed facilitate people in doing daily activities, starting from causation messages, assignments and communicate online, rummage around fo $r$ and get several things by online, order tickets and modes of transportation on-line and plenty of others (Sukmawati \& Nensia, 2019). 
Universitas Megarezky, as one of the Universities in LLDikti IX, was very responsive to respond to this pandemic and took steps related to prevention of COVID-19 transmission by eliminating the activities on campus in the middle of pandemic. Officially, through the circular letter of the rector of Universitas Megarezky No.: 473.091056/III/2020 that as of March 21-31, 2020 the study at Unimerz continues to run via online learning by utilizing Euniversity facilities or others. Furthermore, because this pandemic is not yet ended, then through circular letter of the Rector of Unimerz No.:480/09056/I/2020 about Unimerz of academic policy regarding the Covid-19 pandemic. Especially about the process of education and teaching through online learning. Students' activity in building their own knowledge is a priority in science learning. They are expected to be more independent in constructing their knowledge during the learning process (Sujarwo et al., 2019). Then, learning activities that were previously done by the face to face method in the classroom switched to the online learning system. The concept of social distancing, and physical distancing requires everyone to stay home so that the spread of this virus is not expanding (Deli \& Allo, 2020).

The aims of this study are learners certainly have their own perspective on online learning in the midst of COVID-19 pandemic. Research to date provide insufficient reference regarding the students' perspective on the online learning conducted during COVID-19 pandemic. Meanwhile, the mentioned perspective could be an input for lecturers and institutions to improve online learning quality. Thus, the purpose of this study is to investigate the learners' perspective on Online Learning in the midst of a COVID-19 pandemic.

\section{Sudents' Perspective}

Perspective is an internal process which has been recognized by individual when selected and regulated stimuli that come from outside. This stimulus is captured by one's senses, then spontaneously individual feelings and thoughts will give meaning to the existing stimuli (Aw, 2010). Perspective is a way of looking at a problem that occurs or a particular point of view used in seeing a phenomen (Martono, 2010). Perspective Study is not just looking at the situation, but here students learn, broaden their horizons, and become a new platform to prepare themselves in the future. In perspective students can provide opportunities for them to broaden their horizons and perspectives on the world of work based on the experiences of students.

\section{Online Learning}

Online is as media has many designations in academic literature, including cyber media, digital media, virtual media, e-media, network media, and new media (Nasrullah, 2014). 
With the event of Information and Technology, some of us do innovation to form IT that may be accustomed facilitate others in doing daily activities, starting from causation messages, assignments and communicate on-line, explore for and obtain several things by on-line, order tickets and modes of transportation on-line and plenty of others (Luaran et al., 2014). Online learning is education that takes place over the net. it's usually said as "e-learning" among different terms. However, on-line learning is simply one form of distance learning. According to (Fitriyadi, 2013) shows that a number of the potential edges of ICT for education are: functioning as associate degree enablerfor long learning; create changes within the teacher's role in teaching and therefore the role of scholars in learning; offer open access to interactive material and data through networks; eliminate time and area constraints within the learning environment; support the organization and management of learning and education; and open opportunities for collaboration between academics and between students. moreover, they're accustomed planning project-based learning activities. Therefore, when the COVID-19 outbreak compelled all schools to close and students to learn from home, they hardly faced adjustment issue. At worst, however, learning is just not going down for several students. Their academics lack resources to have interaction in online learning and lots of students do not have access to web association and therefore the necessary gadgets (Lie, 2020)

\section{Materials and Methods}

This research applied qualitative descriptive by focusing on survey to provide a useful empirical investigation from number of people about topic or particular issue. There were 40 students as sample from the four study programs: Elementary School Teacher Education, Physical Education, Sociology Education and English Education of Universitas Megarezky in academic year 2019/2020. The researcher utilized purposive sampling involving a number of students who had a good network to access online learning in the midst of covid-19 pandemic. The research instrument was questionnaire that was obtained by google form and depth interview. Questionnaire is data collection technique that is done by giving a set of written statements to the respondent to answer (Sugiyono, 2018). In this study the form of research used was survey research. Survey techniques are used to gather information from a number of people about a particular topic or issue (Gunawan, 2017). A questionnaire was utilized to collect data from sample to describe about perspective of using online learning. This questionnaire consisted of 30 items, as open-closed-ended questionnaire. The analysis data was obtained by google form by analysing participants' respondents to know their perspective to use online learning, in order to obtain data needed, then data were analysed 
and described to obtain answers to questions. The indicators of the questionnaire consist of four indicators:1) the response of students in the ease of access when learning online, 2) understanding of material in online learning, 3) the effectiveness of online learning, 4) The use of online learning in practicum. Afterwards, the researcher interviewed the learners by calling them by using WhatsApp voice call/video call.

\section{Results and Discussion}

Questionnaire Results

The numbers of population were 222 students from the fourth study program (Elementary School Teacher Education, Physical Education, Sociology Education and English Education of Universitas Megarezky in academic year 2019/2020. There were 40 students as sample. Furthermore, data that has been obtained are described in detail in each aspect as follows:

Before pandemic occurred, the lecturers always taught through face to face. The material is explained by the lecturers in front of the class, then continued with interaction by giving student feedback, and there is usually an assignment at the end pedagogically. From the results of the questionnaire data that has been distributed by researchers to students of FKIP Megarezky University through Google form, as many as 30 items. Students responded that prior to the Covid-19 Pandemic period, they did not use Online Learning before in fact they had used online learning but they did not understand what online learning was like, but during the Covic-19 pandemic, students' perspectives changed, they could understand correctly that online learning was carried out before the Covid-19 pandemic through the WhatsApp Group, Edmodo, Google Classroom etc. The sequence of types of Online learning types that students use during Covid 19 namely: 1. WhatsApp, 2. Zoom, 3. Google Classroom, 4. Telegram and others. Students enjoy learning through online learning. And the application that is widely used by lecturers is WhatsApp. This is in accordance with the results of student responses below:

40 tanggapan

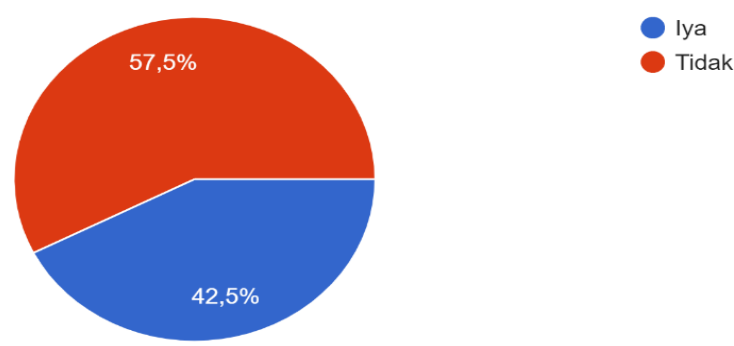

Figure 1. Student responses to online learning before the Covid-19 Pandemic period 
Based on figure 1 stated that the students prefer not to use online learning (57.5\%) before the pandemic because learning was more directed in the classroom. Face-to-face meetings were more dominant before the Covid-19 pandemic.

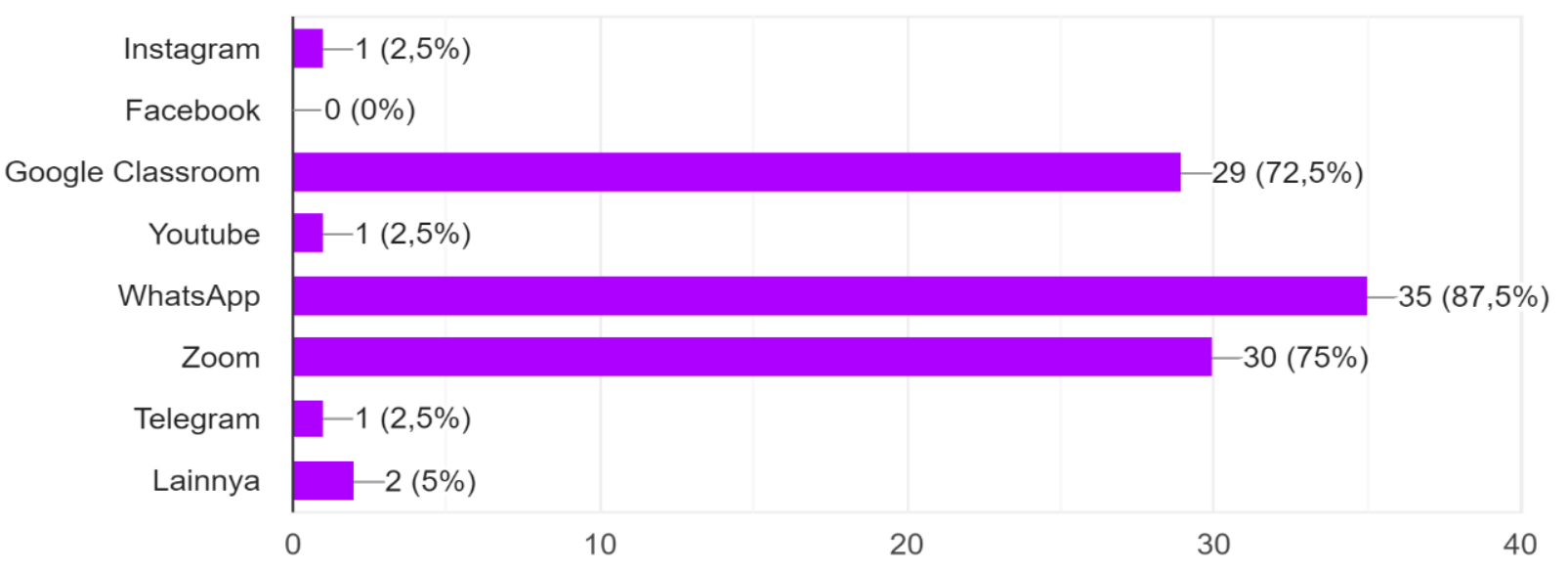

Figure 2. Types of Online learning that students use during Covid -19.

From the diagram above illustrates that students were more dominant in choosing WhatsApp as an application in online learning (87.5\%). This is due to WhatsApp is easily accessed wherever located. Voice note and chat features on WhatsApp make it easy for students to interact both lecturers and students. Then zoom is in second place where this zoom makes it easy to meet face to face.

40 tanggapan

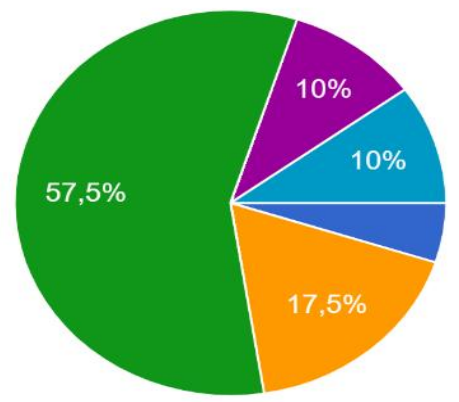

Komunikasi dengan dosen/guru

Komunikasi dengan orang tua

Sinyal Operator Selular

Biaya Kuota Data

Peralatan tidak memadai (HP, Laptop, dII)

Perkuliahan/pelajaran membuat saya cepat bosan

Yang lain:

Figure 3. Students' interest through online learning

During the covid-19 pandemic that required study from home (SFH) to have a positive impact. Seen from the results of a questionnaire distributed to FKIP Megarezky University students showed an attitude of agreement (47.5\%) with online learning. Even though the 
activity is held at home, the teaching and learning process can still be carried out through online learning.

40 tanggapan

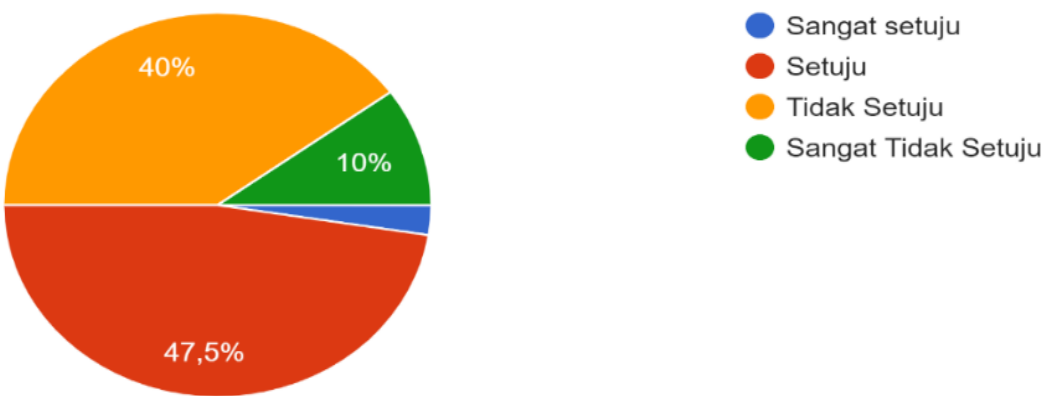

Figure 4. Problems faced by students while studying from home (Online learning)

Online learning used in the covid-19 pandemic turned out to have an impact on students in carrying out the teaching and learning process. These involved students having to pay for higher data quota than before the covid-19 pandemic. Then, students were slower access $(57.5 \%)$ in remote area than students in the city. So, the students had difficulty to interact. This makes students feel bored because of inadequate equipment.

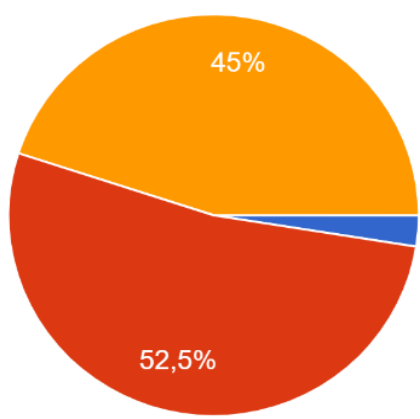

Tetap belajar melalui pembelajaran Online

Kembali belajar di kampus

Campuran antara Online dan belajar di kampus

Figure 5. After passing through the Covid-19 Pandemic period, students want a learning model on campus (back to the campus).

After Covid-19 pandemic period ended, students still chose the learning process to take place in the classroom $(52.5 \%)$. They argue that the interactions were in the classroom made it easier for them to understand the material being studied and more clearly. The ability that students had in one class were not the same, they needed direct guidance. 


\section{In- Depth Interview}

The researchers also collected data by using interview to the students, there are several items of interview such as:

What do the students think about learning online?

St A: In my opinion, online learning really helps us in a situation like now, and the time used is very flexible, wherever we can join to learn online

St B:In my opinion online learning is very helpful into emergency situation nowadays in the plague time of covid-19.

St C: In my opinion online learning has positive and negative impact, it can learn anywhere, then the negative impact is without pause. We use handphone anytime and anywhere, sir.

The results of interview above said that online learning can be implemented anywhere and everywhere. This is line with Sujarwo, Sukmawati, Yahrif (2019) who believe that learning activity can be done easily by learners everywhere as it is not limited by space and time. Online learning seems to be the best option to conduct teaching and learning process in situation of pandemic covid-19, especially, for the students whose have a good network can access online learning well. Nevertheless, online learning has a negative impact. The students have difficult to access online learning because of adequate network and have to use handphone constantly.

Which one is better between the options of online learning and offline learning?

St $C$ : In my opinion, offline learning is better because they can meet directly with lecturers and easier to be understood

St D : I think it's better to go to offline learning sir because if we join offline learning, the material presented by the lecturer is easier to be understood than online learning sir)

St E: I think Offline learning sir.

Based on interview above, the students mostly choose offline learning because they can be face to face with lecturer and friends. They can share ideas directly and make a group without obstacle such as bad network or limited quota. Material presented in the classroom make them easier to comprehend material than online learning. In addition, the available time is much more than online learning because there are low respondents from other friends who have a bad network to participate in learning process. 
How is learning and absorption process of online learning in the Midst of Covid-19 Pandemic?

St $F$ : in my opinion sometimes understood, sometimes it is not understood but lectures face to face is better

St $G:$ Actually, if it is said absorption depends on the method of teaching

St $H$ : It's very inefficient sir, especially when we live in a remote area which basically has not been able to reach an adequate network.

The result of review above said that material can be absorbed based on method of teaching through online learning and network. The students comprehend material when lectures previously give explanation then make a discussion and give assignment. In addition, they now are in different area in which not all have a god network to access online learning. This becomes obstacles to comprehend material because their handphone do not have adequate network.

What is students' expectation after Covid-19 Pandemic ended?

St $C$ : Want to quickly go to offline mode

St F : We hope after Covid -19 ended that Online Learning will continue when it is needed, for example when the Lecturer is unable to enter, online assignment is one of the solutions The result of interview above said that students expected to be back in the normal situation in which they can do activity of learning in the classroom. Nevertheless, online learning can be used when lecturer has another activity in the same time as meeting. So that learning can run well.

What is the suitable application is used by lecturers in teaching using online in the Midst of Covid-19 Pandemic?

St A : WA is good

St D : From the several application options given, I prefer choose via Whatsapp because saving quota it is also very good to use even in bad network conditions, and the most inefficient is via zoom, especially at this time the rise of accounts affected by Hack from this application and unable to use in an unstable network that makes it difficult for us to understand the material provided when the connection is bad, and of course this application is very wasteful of quotas.

St F : I think Via WhatsApp is the application that I like so much because WhatsApp is economical and we can easily access anything, It can be VN, Write, VC. The online learning 
application that I don't like is Zoom cloud Meeting, because it spends a lot of good quota $(K B)$, and has limited time.

Based on the students' responses about the suitable application is used by lecturers in teaching using online in the Midst of Covid-19 Pandemic, the students preferred WhatsApp application because WhatsApp is economical and we can easily access anything, can be using the feature of Voice Notes, chat or Video Call. The online learning application that they did not like is Zoom cloud Meeting, because it spends a lot internet quota, time is limited and the rise of accounts affected by Hack from this application and unable to use in an unstable network that makes it difficult for us to understand the material provided when the connection is bad.

Based on the results of questionnaire and in - depth interview given to students, it is very clear that students experienced challenges, for example they said that their abilities were different, some students understood the learning material if the lecturer explained the material first. Furthermore, the issue of data quota costs that had to spent per month ranges around $101.000-150.000$. Then students felt the use of online learning was so long, chat facilities and voice notes in online learning help them in maintaining social relationships. In addition, online learning can assist students in exchanging information and ideas during Covid-19. Online learning increased interest and motivation. The perspective of students from the four study programs (English Education, Sociology Education, PGSD and Physical Education) under the Faculty of Teacher Training and Education (FKIP) Megarezky University was positive. They believe that online learning had a positive impact in the midst of the COVID19 pandemic. This is proven by the results of research that students find online learning very helpful in the midst of a pandemic. In line with Popovici and Mironov (2014) revealed that students are well aware of the changes brought about by digital technology, by their impact on the learning process.

The spread of the Covid-19 pandemic rapidly hits the world, it has caused lecturers and students have to struggle with this situation. Situation previously had a face-to-face learning process, with direct guidance to meet physically with lecturers in class became something that could not be carried out anymore. With different circumstances not as usual and with different learning processes students are required to continue to have enthusiasm for learning activities. From the results of the research that has been written above, students are still awake in their spirit of learning or their learning activities are still in good condition even though the condition of the emergency response period require study or activity at home. 
This study provides a picture of how online learning in the midst of the COVID-19 pandemic was conducted and institutional challenges faced by the students such as good internet access, financial problems, and implementation of online learning for students. Students expect that financial issues could be reduced if institution could facilitate them with free applications of Online Learning System. This unfortunate phenomenon is also found by Mamattah, R., (2016) who stated that the majority of respondents think it is more expensive to offer courses through e-learning than face-to-face learning entirely. Consequently, if a decision is made based on the choice of learning mode most respondents will go for studying in the real class rather than e-learning. In addition, this research shows that individual task is more effective to maintain social-distancing; however, group task seems to be better in a way that it enables students to help friends who do not have adequate internet credit and access. For these unfortunate students, they would not have equal chance to familiarize themselves with ICT. This situation is unfortunate as Mislinawati, V., M., (2018) believes that students' familiarity with ICT plays an important role in familiarizing themselves with e-learning. Moreover, the study provides evidence that students face difficulty in the online learning. They expect to be given more effective scaffolding from teachers during their learning. For example, the material and assignments must be preceded by an explanation. This is in contrast to what found by Mislinawati, V., M., (2018) that students believe using web-based module was easy.

\section{Conclusion}

Based on the results of the research above, despite the challenges that they face, it can be concluded that the students have favourable perspective on online learning in the midst of COVID-19 pandemic. They consider online learning to be very helpful, although not entirely efficient, in the midst of a pandemic. The existence of several obstacles in the implementation of online learning is expected to be an evaluation in the future so that it is always ready when faced situation like this. Based on the perspective of students in this research related to online learning in the midst of COVID-19 pandemic, government, teachers and school should do efforts to accommodate students' condition such as lack of financial support and internet access availability. In addition, the study provides evidence that whatsApp applications could be an effective and efficient platform as it is cheap and has supporting features (chat, voice notes, and video call) for learning. Future researchers could explore this topic by applying more rigoruos data analysis method, involve more subjects and contrasting more variables. 


\section{Acknowledgments}

I would like to say thanks to all study program of Elementary School Teacher Education, Physical Education, Sociology Education and English Education of Faculty Teacher Training and Education (FKIP) Universitas Megarezky in supporting researchers to complete this research.

\section{References}

Aw, S. (2010). Komunikasi Sosial Budaya. Graha Ilmu.

Cole, M. T., Shelley, D. J., \& Swartz, L. B. (2014). Online instruction, e-learning, and student satisfaction: A three year study. International Review of Research in Open and Distance Learning, 15(6), 111-131. https://doi.org/10.19173/irrodl.v15i6.1748

Deli, M., \& Allo, G. (2020). Is the online learning good in the midst of Covid-19 Pandemic ? The case of EFL learners. Jurnal Sinestesia, 10(1), 1-10.

Fitriyadi, H. (2013). Integrasi Teknologi Informasi Komunikasi Dalam Pendidikan: Potensi Manfaat, Masyarakat Berbasis Pengetahuan, Pendidikan Nilai, Strategi Implementasi Dan Pengembangan Profesional. Journal of Technological and Vocational Education, 12(3). https://doi.org/https://doi.org/10.21831/jptk.v21i3.3255

Gunawan, H. (2017). Dasar-Dasar Metodologi Penelitian Pendidikan. Fakultas Tarbiyah dan Keguruan UIN Sunan Gunung Djati, Bandung.

Hasanah, A., Sri, A., Rahman, A. Y., \& Danil, Y. I. (n.d.). Analisis Aktivitas Belajar Daring Mahasiswa Pada Pandemi COVID-19.

Jamaluddin, D., Ratnasih, T., Gunawan, H., \& Paujiah, E. (2020). Pembelajaran Daring Masa Pandemik Covid-19 Pada Calon Guru: Hambatan, Solusi dan Proyeksi. Karya Tulis Ilmiah UIN Sunan Gunung Djjati Bandung, 1-10.

Lie, A. (2020). COVID-19 disruption and the widening digital divide. https://www.thejakartapost.com/academia/2020/05/02/covid-19-disruption-and-thewidening-digital-divide.html

Luaran, J. @ E., Samsuri, N. N., Nadzri, F. A., \& Rom, K. B. M. (2014). A Study on the Student's Perspective on the Effectiveness of Using e-learning. Procedia - Social and Behavioral Sciences, 123, 139-144. https://doi.org/10.1016/j.sbspro.2014.01.1407

Mahase, E. (2020). Coronavirus: covid-19 has killed more people than SARS and MERS combined, despite lower case fatality rate tle. The BMJ, 2(1), 150-159.

Mamattah, R., S. (2016). Students’ Perceptions of E-Learning. Linköping University.

Martono, N. (2010). Metode Penelitian Kuantitatif. Jakarta: Rajawali Pers.

Mislinawati, V., M., \& N. (2018). Students' perceptions on the implementation of e-learning: Helpful or unhelpful? Students' Perceptions on the Implementation of e-Learning: Helpful or Unhelpful? 
Nasrullah, R. (2014). Teori dan Riset Media Siber (Cybermedia). Jakarta: Prenamedia Group.

Popovici, A., \& Mironov, C. (2014). Students' perception on using eLearning technologies. Procedia - Social and Behavioral Sciences, 180, 1514 - 1519.

Rajab, M. (2020). Pendidikan di tengah pusaran wabah corona detikNews. In Jakarta. detikNews

Rusdiana, A., Sulhan, M., Zaenal, I., \& Ahmad, A. U. (2020). Penerapan Model POE2WE Berbasis Blended Learning Google Classroom Pada Pembelajaran Masa WFH Pandemic Covid-19. 1-10.

Stefanovic, D., Drapsin, M., Nikolic, J., Scepanovic, D., Radjo, I., \& Drid, P. (2011). Empirical study of student satisfaction in e-learning system environment. Technics Technologies Education Management, 6(4), 1152-1164.

Sugiyono. (2018). Metode Penelitian Kuantitatif,. Bandung: Alfabeta.

Sujarwo; Sukmawati;Yahrif, M. (2019). Model-Model Pembelajaran: Pendekatan Saintifik dan Inovatif (Jalal (ed.)). Serang Banten: CV.AA.Rizky. www.aarizky.com

Sujarwo, S., Akhiruddin, A., Salemuddin, M. R., Sabillah, B. M., \& Sriwahyuni, S. (2019). The Application of Problem Solving Reasoning (PSR) in Improving Students' Metacognitive at the Twelfth Grade Students of SMAN 19 Makassar. International Journal for Educational and Vocational Studies, 1(2), 138-141. https://doi.org/10.29103/ijevs.v1i2.1525

Sukmawati, S., \& Nensia, N. (2019). The Role of Google Classroom in ELT. International Journal for Educational and Vocational Studies, 1(2), 142-145. https://doi.org/10.29103/ijevs.v1i2.1526

Suminar, A. (2020). Dampak covid-19 terhadap ekonomi global 2020. Surabaya. suarasurabaya.net

Yanti, M. T., Kuntarto, E., \& Kurniawan, A. R. (2020). Pemanfaatan Portal Rumah Belajar Kemendikbud Sebagai Model Pembelajaran Daring di Sekolah Dasar. Jurnal Pendidikan Dasar. 